\title{
Growth and Employment Considerations in the Food vs. Export Crops Debate
}

\section{Alan Matthews}

\section{Introduction}

There is a growing interest in policies of food selfsufficiency in developing countries. For exarrple, the Lagos Plan of the Organisation of African Unity explicitly commits its signatories to achieve selfsufficiency in food production and supply for Africa. There are similar concerns in Asia and Latin America [World Bank 1986:78]. This new concern in developing countries is paralleled by a widespread disposition in the more popular development literature to see dependence on agricultural exports, particularly by food-deficit developing countries, as undesirable. It is argued that food production to meet local consumption needs should be given priority, and only subsequently should LDCs engage in international trade to exchange surplus agricultural production for other goods and services [George 1976, Lappé and Collins 1980].

It is often argued that food production in LDCs has been discriminated against and export agriculture favoured in the allocation of investment resources, research budgets, input subsidies and other policy measures. Where this is the case, there should be significant efficiency gains from switching resources to the food production sector. Advocates of trade on the basis of comparative advantage and proponents of food self-sufficiency will agree in this instance. According to Valdès [1987:582], 'Positive nominal protection in many developing countries . . . can be viewed as partial compensation for significant discrimination against agricultural import-substitutes resulting from an overvalued exchange rate, high levels of industrial protection, and macroeconomic policies that favour industry over agriculture'.

The more interesting situation is one where comparative advantage as conventionally measured appears to lie with export crops. For example, domestic resource cost (DRC) calculations for food and export crops in Africa show a strong comparative advantage in export crops [World Bank 1981]. An export-sacrificing policy of concentrating on food selfsufficiency would be very costly in terms of income. Despite the apparently high cost of pursuing food self-sufficiency, various arguments are put forward to justify it as the more desirable policy.

First, it is argued that the structure of the international trading system is biased against tropical exports. The likelihood of declining international terms of trade, the greater prospect of price and export income instability, and the political and economic risks of relying on world markets for essential food supplies combine to out weigh any static gains from the pursuit of comparative advantage.

Second, export agriculture is held likely to worsen the already precarious position of the poor majority within developing countries. It is argued that rural poverty and hunger are increased by the competition between food and export crops for scarce capital, land and other inputs, and by the impetus given to the concentration of land use and ownership.

Third, export-oriented agriculture is criticised for its limited growth effects at the national level arising from the paucity and nature of its linkages with the remainder of the national economy. Thus despite the private advantage to commodity producers in cultivating export crops, it is believed that the social interest would be better served by a more autarkic policy.

This article is concerned with the third of these issues. The question it asks is: is there a case for granting protection to the food-producing sector in food-deficit countries on growth and employment grounds? This issue is addressed by drawing an explicit parallel between the debate over import substitution industrialisation (ISI) and food self-sufficiency, or agricultural import substitution (AIS), strategies. In the next section possible arguments to justify agricultural import substitution on growth and employment grounds are evaluated. The subsequent section considers the potential of empirical studies to throw light on the question. Irish agricultural policy in the 1930 s is then briefly considered as a case study of a food self-sufficiency episode. The final section summarises the article's conclusions.

\section{Agricultural Import Substitution Evaluated}

The literature on import substitution strategies until now has been solely concerned with industrial policy. Because agricultural imports have been an insignificant proportion of both total imports and total agricultural production the potential for AIS as a development strategy was very limited. State intervention in LDCs 
discriminated against domestic agriculture rather than providing it with protection. This section evaluates the arguments for an import substitution strategy in the agricultural sector on growth and employment grounds.

There are a number of arguments used to justify ISI which are clearly not relevant to AIS. The "infant industry' argument for temporary protection of a newly-established industry when its costs are high because of lack of experience and various 'teething problems' is one. The 'market identification' argument, that imports prove the existence of a ready market and thus that import substitution is an 'easier' route to increasing production than exporting, is not relevant either. For traditional export crops the argument has little force. For more exotic exports, subsidies to overcome the marketing barriers will be a more costeffective solution than turning inward to the domestic market. The 'market protection' argument, where the purpose of protection is to encourage TNCs to establish domestic production facilities if they wish to retain their market position, does not play a significant role either. The existence of open or disguised unemployment, particularly in agriculture, is also used to justify the protection of domestic manufacturing industry. Whatever the validity of this argument for industrial protection it is clearly not relevant to the food versus export crop production decision. This still leaves a number of arguments which are used in the industrial import substitution debate which could be relevant to AIS.

Export pessimism, or the expectation of a sharp deterioration in the terms of trade for primary commodity exports, was an important factor in the early arguments for ISI. It was reinforced by the fear of protectionism in developed countries if competitive pressures grew too great. In the context of agricultural strategies the relevant issue is the movement in the terms of trade between LDC export crops and food crops for the domestic market. If comparative advantage is properly interpreted as long-run advantage taking account of medium term trends in relative prices, no conflict of principle should exist between liberal trade and food self-sufficiency theorists. In practice, it is a major dispute of fact between the two schools. The issue is complicated in the agricultural context by the high and widespread protection granted to food production in the developed countries, which has lowered world market prices for food. Even comparative advantage supporters are reluctant to advocate that existing world market prices are suitable reference prices for LDC decision-makers, and have advocated compensating protection in return.

Second, there is the fear that reliance on trade will heighten instability problems for the domestic economy. Countries which adopt a liberal approach to agricultural trade policy will experience more instability than countries which pursue a food selfsufficiency strategy and make use of trade only to dispose of occasional surpluses or to make up occasional shortfalls [Storey 1987]. The importance of the argument depends on the extent of the adverse effects of instability for growth in the wider economy, on the costs of pursuing stability in this way, and on whether alternative policies to offset the effects of instability are available.

Third, there is the balance of payments argument. With most LDCs facing a severe foreign exchange constraint the prospect of saving foreign exchange by substituting domestic production for imported foodstuffs will be attractive to many countries. However, if comparative advantage has been correctly calculated then less foreign exchange will be saved by using domestic resources in food production than could be earned by applying the same resources to export crop production. A particular argument for expanding domestic food production exists if a country's import needs are large relative to world trade (the optimal tariff argument), but this argument is unlikely to be relevant for food-deficit LDCs.

Fourth, greater spillover effects for the rest of the economy from a food production strategy have been suggested. Spillover effects depend on the existence of linkages, and thus the argument must be that the domestic food production sector is more closely integrated into the rest of the economy than the export crop sector. Various types of linkages can be defined: employment linkages, forward linkages, backward linkages, fiscal linkages and consumption linkages. Certain dynamic linkages, such as the creation or transfer of management skills, technology, human capital or social overhead capital may also be important. The implication of one sector having fewer linkages than another is that the private interests of agents in that sector will not correspond with the wider social interest, and should be overridden.

The debate about linkages is closely bound up with the fact that in many LDCs agricultural exports are associated with foreign-owned plantation enterprises. Critics point to the high leakages abroad in the form of imports and remittances of earnings, and to the greater likelihood that technology with low domestic content will be used. Arguably, this criticism is directed at the mode of ownership of agricultural production rather than related to any inherent characteristics of crops grown for the domestic or export markets. In practice, in the case of exotic products, for example, it may not be possible to have one without the other.

While the growth and employment arguments for protection and an inwardly oriented agricultural development strategy rest on the alleged presence of market imperfections which limit the development 
prospects of LDCs, proponents of comparative advantage point to the costs associated with protectionist policies. The major arguments may be summarised as follows.

First, whereas ISI has been criticised for inherent stagnationist tendencies once the easy phase of import substitution is over, AIS has an even more obvious limitation as a development strategy because once self-sufficiency is reached further growth is limited to the growth in domestic market demand. The export of protected commodities will only be viable with the aid of export subsidies, the cost of which can quickly spiral out of control, as the EEC has found to its cost.

Second, the hope that AIS will reduce the severity of the balance of payments constraint on development will prove largely illusory. Even food production for the domestic market will require inputs and capital goods from abroad. Also, the protectionism required to ensure the success of AIS will diminish the likelihood of successful exporting by other sectors (by encouraging the maintenance of an overvalued exchange rate and by raising the cost of an important wage good to the non-food part of the economy).

Third, there is the high cost of an AIS strategy arising from the substitution of higher-cost domestic production for low-cost imports, although this cost might be relatively smaller for AIS compared to ISI. Because economies of scale are important in industrial production, production for the domestic market alone often means small, high-cost plants. Economies of scale play a much smaller role in determining the excess cost of domestic food production, although as against this climatic and natural resource factors play a correspondingly larger role. The dynamic losses from the lessening of competition which play a large role in the ISI debate are also less relevant to AIS. European experience suggests that in agriculture protection and rapid technological advance go hand in hand.

Fourth, there will also be efficiency losses from the administration of an AIS policy. Where quantitative restrictions are used, unintended high rates of protection can result. It is also very difficult to maintain consistent incentives across the board. The very high variation in protection levels, and especially effective protection levels, increases distortions and thus costs. The bureaucratic costs in implementing an AIS strategy can also be significant.

\section{Approaches to Empirical Testing}

A priori reasoning can only go some way to throwing light on the merits of the case for AIS on growth and employment grounds, and should be complemented by empirical tests. One approach would be to use a cross-country reduced form model in which a variable representing the attainment of a macroeconomic goal such as growth or employment is regressed on some indicator of the trade orientation of agricultural strategy for a sample of countries. The method frequently used in empirical studies of ISI is to introduce an export variable into a sources of growth equation. For example, using a neoclassical production function, the model becomes

$$
\mathrm{Y}=\mathrm{f}(\mathrm{K}, \mathrm{L}, \mathrm{X})
$$

where the symbols have their usual meanings. Where data on factor use are unavailable, an alternative specification due to Krueger [1978] has been used:

$$
\mathrm{Y}=\mathrm{f}(\mathrm{t}, \mathrm{X}, \mathrm{D})
$$

where $t$ is a time variable intended to pick up the impact of each country's structure on its growth rate, and $D$ is a dummy variable representing the ISI or more export-oriented phase respectively. Krueger reviews the results of earlier studies of this kind, all of which support the view that export growth is associated with a favourable effect on the overall growth rate. It may prove difficult to apply a similar approach to evaluating agricultural trade strategies because of the problem of disentangling their impact from the many other factors affecting overall growth rates.

A second approach is to use models of developing economies such as input-output models, socialaccounting matrix-based macromodels or macroeconometric models to investigate how activity in the food and export crop sectors affects savings, government revenue, investment, foreign expenditure, wages and so forth. To use these models the effect of alternative strategies on overall growth rates is abstracted from, and attention is focused on the impact on growth and employment of a balanced expansion and reduction in food and export crop production. The impacts are expected to differ because of the different linkages between the production sectors and the remainder of the economy.

Where large-scale models are not available, farm management-type crop budget data could be used to throw light on some of the relevant linkages. In the case of employment, for example, the export crop systems traditionally associated with LDCs - coffee, cotton, cocoa, tea, rubber, etc. - tend to require relatively large labour inputs per unit of land and of output when grown on a small-scale basis (see the evidence of labour requirements for selected food and cash crops produced in the Tanzanian peasant sector in Odegaard 1985]. Some writers make use of the concept of retained value (RV), or the proportion of the final value of output paid locally, as a summary measure of an activity's development contribution. Thoburn [1977] reviews several studies of this type which are principally concerned with export products.

An important conclusion is that the $R V$ rate is significantly influenced by the technology of pro- 
duction and, indirectly, by patterns of ownership. One danger with this measure is that the relative amount of linkage becomes an end in itself, whereas the developmental contribution is presumably associated with the absolute amount of linkages, regardless of the RV proportion. Also, RV studies do not seem to have dealt explicitly with the food versus export crop issue.

Direct employment and domestic input coefficients may give a misleading picture of the overall employment impact because indirect effects in other sectors are ignored. Data from input-output tables can throw light on this issue. Odegaard quotes a Tanzanian study by Kim [1976] which shows that cash crops have a more favourable effect, for a one unit increase in final demand, on national income, wage earners' income and the balance of trade. The greater impact on wage earners' income implies that the overall employment effect following an increase in exogenous final demand for cash crops will be higher than for food crops, consistent with the Tanzanian experience that the labour intensity of cash crop processing is higher than for food processing. However, an inputoutput study by Devi [1986] of linkages in Kerala, India, where plantation crops account for 38 per cent of the cultivated area comes to the opposite conclusion. Devi shows that the linkages of the agriculture and animal husbandry sector with the rest of the economy are much better than the plantation sector, and concludes that the present trend in Kerala of converting the lands under paddy into cash crop cultivation need to be viewed with alarm. Clearly these differences need much fuller consideration, and a survey of the available evidence would be a useful start.

A final approach is to undertake careful historical evaluation of individual country experiences on a case study basis. The next section considers the Irish case.

\section{The Irish Experience}

The Irish experience during the 1930s provides a useful case study to investigate the effects of implementing a policy of food self-sufficiency in a developing country [Crotty 1966, Lyons 1973]. There are many parallels between the Irish economy then and Third World economies today. Irish living standards (measured in terms of national income per capita) were 60 per cent of those in the United Kingdom at the beginning of the 1930s. 51 per cent of those gainfully occupied were employed in agriculture, which contributed 32 per cent of total national income. Extensive cattle-raising was the dominant agricultural activity, and its gradual spread over the previous century had led to a fall in labour requirements in agriculture and to large-scale emigration.

The agricultural policy pursued by the newly independent Free State after 1922 was contentious.
The opposing views were aired by the 1923 Commission on Agriculture, which issued both a majority and minority report. The majority report recommended a continuation of the free trade framework which had governed agricultural policy throughout the period of Union with Great Britain. It opposed the grant of direct assistance by tariffs, subsidies or guaranteed prices on the ground that these would ultimately be paid for by the agricultural community itself. This advice was followed by the Free State government during the 1920s. It followed that production continued to concentrate on dry cat tle where comparative advantage clearly lay.

The opposing view was stated in the minority report of the 1923 Commission. It held that the national welfare would be best served by the direction of agriculture:

firstly, to satisfy the needs of the people of this country, and secondly to supply the demand from other countries for commodities of a quality or kind which we can produce to advantage, and to exchange these for commodities which we cannot produce or which we can only produce at an exorbitant cost [1923:79].

With the coming to power of the Fianna Fail government in 1932, committed to a policy of both agricultural self-sufficiency and industrial protection, these views became the objectives of government policy. Important growth and employment benefits were expected to follow from a shift from extensive cattle to intensive tillage farming. Given the seriousness of unemployment and emigration, the national interest was seen to lie in the development of dairying and tillage production which would afford more employment and a higher gross output per hectare, even though the net output per hectare to the farmer himself might well be less.

The main lines of the new agricultural policy involved a reduction in the production of cattle for export, the maintenance of the export trade in butter, eggs and bacon, and an increase in the domestic production of agricultural products previously imported, particularly wheat, feedgrains, fruit, vegetables, sugar and tobacco. Incentives in the form of market protection and guaranteed prices were introduced to encourage farmers to make the production switch, while a bounty on calf skins was introduced to encourage the reduction in cattle herds. The deliberate slaughter of calves was too much for public opinion, and this scheme had a short life, but the drastic fall in cattle prices resulting from British import duties imposed in the course of a dispute with the Irish Government over the payment of land annuities (prices were 50 per cent lower in the mid-1930s compared to 1931) had a similar effect. Cattle exports, which amounted to 775,000 head in 1929 , dropped to just over half a million by 1934 .

Because the AIS experiment took place in the middle 
of a world depression, a radical change in industrial policy and a trade war with its major trading partner, a definitive evaluation is very difficult. However, it is widely agreed that the policy of 'speeding the plough' was not a success. Agricultural output fell by six per cent in real terms between 1931 and 1938. The acreage under wheat and sugar beet rose (by raising Irish prices well above world levels) but largely at the expense of other tillage crops - taking the year 1930 as 100 , the index number for the total area of tillage was 111 in 1936 and only 102 in 1939 . Crotty dismisses the foreign exchange saving of the tillage policy on the grounds that it may well have been achieved at the cost of an even greater decline in exports, particularly of livestock products hit by the reduction in the oats and potato acreage. He argues that the cost to consumers was far greater than the gain to producers. Furthermore, there was a built-in limit to any further expansion in non-cattle products as additional exports implied an increase in subsidies, which in turn implied a further reduction in living standards.

\section{Conclusion}

The main purpose of this article is to suggest that growing food deficits and the consequent interest in making food self-sufficiency a policy goal is giving rise to a new phenomenon in many LDCs, which I call agricultural import substitution. One of the arguments (nat necessarily the most important one) for food self-sufficiency is the belief that it will yield higher returns in terms of growth and employment creation than the pursuit of conventional comparative advantage in the agricultural sector. The paper has examined the theoretical basis for this expectation. Using arguments drawn from the debate on the impact of alternative trade regimes on industrial development, it is concluded that the $a$ priori expectation of faster growth and employment creation from an AIS strategy is not strong. Where there is a large agribusiness presence in the export crop sector, the spillover linkages from small-scale production of food for the domestic market may be greater, although encouraging small-scale farmers to take up export production would be even more beneficial. The usefulness of different empirical approaches to testing the alternative theories is discussed in a qualitative way. The agricultural import substitution experience of the Irish Free State in the 1930s was then described. Despite the difficulties of isolating its effects because of a number of confounding events which occurred simultaneously, this experience tends to confirm the critics of AIS, while at the same time giving no comfort to advocates of purely laissez-faire policies. The conclusion is that agricultural import substitution strategies are difficult to justify on growth and employment grounds.

\section{References}

Crotty, R., 1966, Irish Agricultural Production: Its Volume and Structure, Cork University Press, Cork

Devi, S. U., 1986, 'Backward and forward linkages of the plantation sector vis-â-vis the others in Kerala's economy, 1973-74', paper read to the 8th International Conference on Input-Output Techniques, Sapporo, Japan, 28 July2 August

George, S., 1976, How the Other Half Dies, Penguin Books, Harmondsworth

Kim, K. S., 1976, 'The linkage effects of basic industries in Tanzania: some policy issues and suggestions', Economic Research Bureau paper no 76.11, Dar es Salaam

Krueger, A., 1978, Liberalisation Attempts and Consequences, Ballinger, Cambridge

Lappé, F. and Collins, J., 1980, Food First, Souvenir Press, London

Lyons, F. L., 1973, Ireland Since the Rising, Pan Books, London

Odegaard, K., 1985, Cash Crops versus Food Production in Tanzania: An Assessment of the Major Post-colonial Trends, Lund Economic Studies No. 33, University of Lund, Sweden

Reports of the Committee on Agriculture, 1923, Stationery Office, Dublin

Storey, A., 1987, 'Agricultural Production Strategies in SubSaharan Africa: Food Self-Sufficiency versus Food SelfReliance', MLitt thesis, University of Dublin, Trinity College

Thoburn, J., 1977, Primary Commodity Exports and Economic Development: Theory, Evidence and a Study of Malaysia, Wiley, London

Valdès, A., 1987, 'Agriculture in the Uruguay Round: interests of developing countries', The World Bank Economic Review' vol 1 no 4, p 571-93

World Bank, 1981, Accelerating Development in Sub-Saharan Africa, The World Bank, Washington, DC

-1986, World Development Report 1986, Oxford University Press, Oxford 